5. Monitorynh sotsialno-ekonomichnoho rozvytku rehioniv za 2018 rik [Monitoring the socio-economic development of regions in 2018]. Retrieved from https://www.minregion.gov.ua/wp-content/uploads/2019/05/Reytingova-otsinka-za-2018-rik-prezentatsiyni-materiali.pdf (accessed 20 February 2019). [in Ukrainian].

6. Reitynh vedennia biznesu u rehionakh 2018 [Regional Doing Business Ranking 2018]. Better Regulation Delivery Office (BRDO); The Union of Ukrainian Entrepreneurs (SUP). Retrieved from http://rdb.brdo.com.ua http://rdb.brdo.com.ua (accessed 20 February 2019). [in Ukrainian].

7. Reyting investitsionnoy effektivnosti oblastey [Regional investment efficiency ranking]. Retrieved from http://euro-rating.com.ua/regiony/rejting-list/rejting-list-oblastej/ (accessed 20 February 2019). [in Russian].

8. Yevromapa Ukrainy. Reitynh yevropeiskoi intehratsii oblastei [The European map of Ukraine. Rating of European Integration of Regions]. (2019). Kyiv: New Europe Center. Retrieved from http://neweurope.org.ua/wp-content/uploads/2019/11/Euromap-ukr-web.pdf (accessed 20 February 2019). [in Ukrainian].

9. Monitorynh protsesu detsentralizatsii ta reformuvannia mistsevoho samovriaduvannia (stanom na 10 sichnia $2020 \mathrm{r}$.) [Monitoring of the process of power decentralisation and local governance reform (10 January 2020)]. Ministry of Development of Communities and Territories of Ukraine. Retrieved from https://decentralization.gov.ua/uploads/library/file/526/10.01.2020.pdf (дата звернення 20.02.2020). (accessed 20 February 2019). [in Ukrainian].

Дата подання публікації 26.03.2020 р.

УДК 338.2:332.12 (1-22)+63(477.82)

\author{
Соколова А.О., к.е.н., доцент \\ https://orcid.org/0000-0003-0194-6706 \\ Ратошнюк T.M., к.е.н., ст. наук. Співробітник \\ https://orcid.org/0000-0002-1097-0874
}

Sokolova A. Candidate of Economic Sciences, Associate Professor Ratoshnyuk T.M. Candidate of Economics Science, Senior Researcher

\title{
СОЩІАЛЬНО-ЕКОНОМІЧНІ НАСЛІДКИ ДЕЦЕНТРАЛІЗАЦІЙНИХ ПЕРЕТВОРЕНЬ НА СІЛЬСЬКИХ ТЕРИТОРІЯХ: РЕГІОНАЛЬНИЙ АСПЕКТ
}

\author{
Волинська державна сільськогосподарська дослідна станиія НААН України \\ Інститут сільського господарства Полісся НААН України
}

Одним 3 основних аспектів аграрної політики України є побудова такої моделі розвитку сільських територій, яка б відповідала стандартам розвиненої європейської країни. Концепт адміністративної децентралізації в Україні ідеологічно сформувався впродовж останніх трьох років після активізації намірів інтегруватися до Європейського Союзу. Процес децентралізації владних повноважень в Україні створив передумови для самостійного соціально-економічного сільського розвитку на базі громад.

Метою даного дослідження $\epsilon$ визначення особливостей здійснення адміністративнотериторіальної реформи на сільських територіях Волинської області та здійснення оцінки сучасного етапу соціально-економічного розвитку об'єднаних територіальних громад 3 метою розробки та обгрунтування науково-організаційних засад та практичних рекомендацій щодо управління соціальноекономічними сільським розвитком регіону. Доведено, що розвиток сільської економіки Волинської області значною мірою залежить від природно-економічних умов, виробничо-ресурсного, фінансового та людського потенціалу й діяльності окремих сільських територіальних громад.

В статті проведено аналіз соціально-демографічної ситуації в області; визначено регіональні особливості перебігу адміністративно-територіальної реформи на сільських територіях Волині; оцінено результати використання бюджетних доходів створених територіальних громад; стан і забезпеченість об'єктами соціальної інфраструктури; ідентифіковано основні проблеми розвитку ОТГ. За допомогою SWOT-аналізу визначено «сильні» та «слабкі сторони» й потенційні можливості та загрози децентралізації для соціально-економічного розвитку сільських територій досліджуваного регіону.

Ключові слова: сільські території, дещентралізачія, об'єднані територіальні громади, соиіально-економічний розвиток.

\section{SOCIO-ECONOMIC CONSEQUENCES OF DECENTRALIZATION TRANSFORMATIONS IN RURAL AREAS: REGIONAL ASPECT}

Volhynia state agricultural experimental station of the National academy of agrarian sciences of Ukraine 
One of the main aspects of the agrarian policy of Ukraine is the construction of such a model of rural development that meets the standards of a developed European country. The concept of administrative decentralization in Ukraine was ideologically formed over the past three years after the intensification of intentions to integrate into the European Union. The process of decentralization of power in Ukraine created the prerequisites for independent socio-economic rural development based on communities.

The purpose of this study is to determine the specifics of the implementation of administrativeterritorial reform in the rural territories of the Volyn region and to assess the current stage of the socio-economic development of the united territorial communities in order to develop and substantiate the scientific and organizational foundations and practical recommendations for managing the socio-economic rural development of the region. It is proved that the development of the rural economy of the Volyn region is largely dependent on natural and economic conditions, production and resource, financial and human potential and the activities of individual rural territorial communities.

The paper analyzes the socio-demographic situation in the region; regional features of the course of administrative-territorial reform in the rural territories of Volyn are determined; The results of using budget revenues of the created territorial communities are estimated; condition and provision of social infrastructure facilities; identified the main problems of the development of OTG. Using the SWOT analysis, the "strengths" and "weaknesses" and potential opportunities and threats of decentralization for the socio-economic development of rural areas of the studied region are determined.

Key words: rural territories, decentralization, integrated territorial communities, socio-economic development.

Постановка проблеми у загальному вигляді i ï̈ зв'язок 3 важливими науковими та практичними завданнями. Свроінтеграційні процеси в нашій країні тісно пов'язані з внутрішніми, які формують сучасну політику розвитку держави, спрямованість на децентралізацію територіальних одиниць, здатну забезпечувати національні інтереси та мають соціальну спрямованість. На шляху до децентралізації проблемним питанням $\epsilon$ оптимізація структури адміністративно-територіальних одиниць в окремих регіонах. Останні характеризуються надзвичайною подрібненістю на базовому рівні, особливо їх сільські території. Тому, розробка, обгрунтування та реалізація науково-організаційних засад й практичних рекомендацій щодо управління соціально-економічними розвитком сільських територій в умовах децентралізації на регіональному рівні є доцільним та набуває нині особливої актуальності.

Аналіз останніх досліджень, у яких започатковано вирішення проблеми. Дослідженню соціально-економічних проблем розвитку сільської місцевості присвячені наукові роботи О.М. Бородіної [1], О.Г. Булавки, В.С. Дієсперова, В.Д. Залізка, В.В. Борщевського [2], Ю.Е. Губені, В.К. Збарського, Т.О. Зінчук [3], М.Й. Маліка [4], Л.І. Михайлової, О.М. Могильного, М.К. Орлатого, О.І. Павлова, I.В. Прокопи [5], К.В. Прокопищак, В.П. Рябоконя, П.Т. Саблука, М.М. Тимошенка [6, 7], В.К. Терещенка, В.А. Ткачука, К.І. Якуби та інших.

Важливу роль для вивчення питань державного управління соціальноекономічним розвитком сільських територій відіграють праці таких науковців, як О. Амосов, В. Дорофієнко, Н. Мельтюхова, О. Мордвінов, М. Корецький, О. Коротич, М. Латинін, В. Мамонова, Н. Нижник, Г. Одінцова та ін. Попри грунтовні наукові напрацювання слід зазначити, що окремі регіональні аспекти цієї проблеми залишаються недостатньо вивченими й наразі необхідними.

Цілі статті - визначити особливості здійснення адміністративно-територіальної реформи на сільських територіях Волинської області та здійснити оцінку сучасного етапу соціально-економічного розвитку об'єднаних територіальних громад 3 метою розробки та обгрунтування науково-організаційних засад та практичних рекомендацій щодо управління соціально-економічним сільським розвитком регіону в умовах адміністративної децентралізації для забезпечення ефективного місцевого самоврядування та ресурсної самодостатності сільських громад.

Виклад основного матеріалу дослідження 3 повним обгрунтуванням отриманих наукових результатів. Сільські території Волині мають потужний не лише 
природно-кліматичний та виробничо-економічний, а й соціальний потенціали, спроможні забезпечити конкурентоспроможне виробництво, стабільне економічне зростання i, відповідно, високий рівень та якість життя сільського населення. На території Волинської області розташовані 11 міст, 22 селища та 1054 села, які об'єднані у сільські, селищні ради та об'єднані територіальні громади (далі ОТГ). Важливе місце в розвитку сільських територій області належить сільській поселенській мережі - рис.

Слід зазначити, що за 2015-2018 рр., відповідно до закону України «Про добровільне об'єднання територіальних громад», в області утворено 51 об'єднану територіальну громаду. Більше 70 \% населення області сконцентровано у центральних і південних районах області, де щільність сягає 75,5 особи на км2 (в середньому по Україні - 75,6). Північна частина Волині заселена рідше - 22,4-36,1 особи на 1 км2, а в середньому по області цей показник становить 51,6 особи на 1 км2. Найбільший район за чисельністю населення Ківерцівський - 63,9 тис. осіб, а найменший - Шацький $(17,0$ тис. осіб).

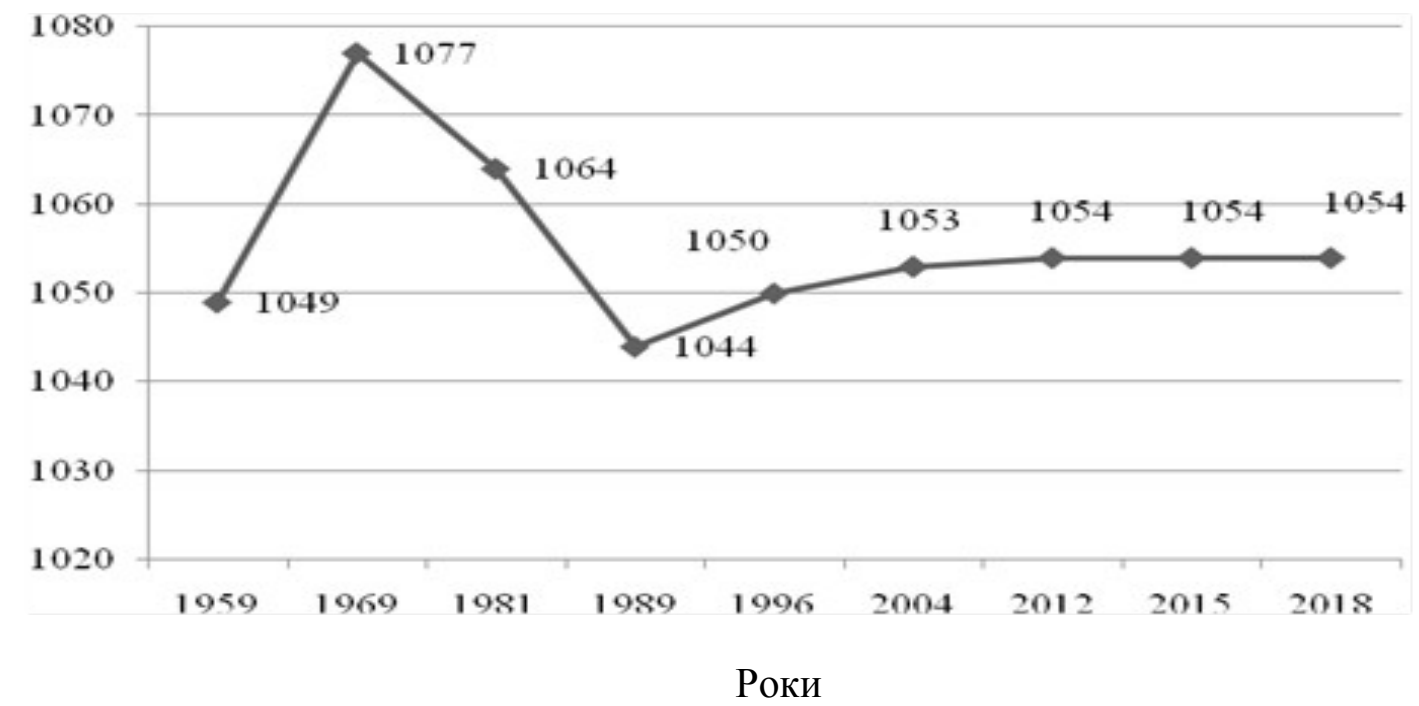

Рис. Динаміка кількості сільських населених пунктів Волинської області Джерело: побудовано за даними [8, с. 24].

Волинська область розташована на крайньому північному заході України, займає 3,3\% території України (20,1 тис. км²), де в 16 районах, містах та селищах міського типу станом на 1.01.2019 р. проживало 1042,9 тис. осіб, що на 1,6 тис. осіб більше, ніж у 2013 році. (табл. 1).

Таблиця 1

Динаміка кількості наявного міського і сільського населення Волинської області станом на 1 січня, тис. осіб

\begin{tabular}{|c|c|c|c|c|c|}
\hline \multirow{2}{*}{ Рік } & \multirow{2}{*}{ Все населення } & \multirow{2}{*}{ Міське } & \multirow{2}{*}{ Сільське } & \multicolumn{2}{|c|}{ Структра, \% } \\
\cline { 5 - 6 } & & 529,3 & 534,1 & міське & сільське \\
\hline 1990 & 1063,4 & 54,8 & 50,2 \\
\hline 2000 & 1067,7 & 544,3 & 523,4 & 51,0 & 49,0 \\
\hline 2005 & 1044,8 & 526,2 & 518,6 & 50,4 & 49,6 \\
\hline 2010 & 1036,7 & 535,4 & 501,3 & 51,6 & 48,4 \\
\hline 2015 & 1042,9 & 545,4 & 497,5 & 52,3 & 47,7 \\
\hline 2016 & 1042,7 & 545,6 & 497,1 & 52,3 & 47,7 \\
\hline 2017 & 1041,0 & 544,6 & 496,4 & 52,3 & 47,7 \\
\hline 2018 & 1038,5 & 542,7 & 495,8 & 52,3 & 47,7 \\
\hline 2019 & 1035,3 & 540,7 & 494,6 & 52,2 & 47,8 \\
\hline 2019 р. до & $-28,1$ & 11,4 & \multirow{2}{*}{39,5} & 2,4 & $-2,4$ \\
1990 р., (+,-) & \multirow{2}{*nnnny}{} & & & & \\
\hline
\end{tabular}

Джерело: розраховано за даними [8, с. 31]. 
Демографічна криза є однією з основних причин напруженості балансу трудових ресурсів сільських територій Волинської області та України в цілому. На сучасному етапі на перший план виступає проблема старіння та вимирання сільського населення. Це явище характерне для України в цілому, і Волинської області зокрема. Абсолютна чисельність постійного населення області за 1990-2018 pp. зменшилась на 28,8 тис. осіб, або на 2,7 \%. Проведений аналіз свідчить про те, що за останні 29 років (1990-2019 рр.) суттєво змінилась структура наявного міського і сільського населення Волинської області в сторону зниження питомої ваги сільського населення на 2,7 \%. Станом на 1.01.2019 р. в сільській місцевості Волині проживало 494,6 тис. осіб, що на 6,7 тис. осіб (1,3 \%) менше, ніж у 2010 р. Якщо чисельність міського населення щороку зростає (на 11,4 тис. осіб за останні 29 років), то чисельність сільського населення зменшується, причому набагато більшими темпами (за останні 29 років зменшилась на 39,5 тис. осіб).

3 демографічної точки зору, села Волинської області надзвичайно старі. У віковій чисельності населення досліджуваного регіону виділяється три групи: населення молодше працездатного віку (0-14 років); працездатного (15-64 роки) і старше працездатного віку (65 років і старші). Аналіз вікової структури сільського населення, свідчить про те, що населення молодше працездатного складає 20,0\%; працездатного - 61,9\%; старше працездатного - 18,0 \% жителів області. Найнижчі показники, які свідчать про негативні тенденції у динаміці народжуваності і смертності сільського населення Волинської області спостерігались у 2000-2005 pр.

Незважаючи на зниження кількості померлих селян у 2006-2011 pp., природний приріст мав від'ємне значення, тобто на 1000 жителів у 2011 р. народилось 15,3 особи, а померло 16,1. Слід зазначити, що у 2012 р. ситуація змінилась на краще, померли 7965 осіб, а народилось 8074, тобто вперше за останні 28 років природний приріст сільського населення був додатній. У 2013-2018 рр. ситуація знову погіршилась: у 2018 р. 3 розрахунку на 1000 наявного сільського населення народилось 12,0 осіб, а померло - 15,5 осіб.

Досліджуючи сільські території як багатофункціональну соціальнотериторіальну систему та проблему управління ними в умовах децентралізації, варто особливу увагу звернути на проблему зайнятості та соціальної захищеності селян. Проведене дослідження свідчить про те, що у сільській місцевості Волині існує приховане безробіття, структурні диспропорції між робочою силою і робочими місцями (табл. 2.).

Таблиця 2 Склад і структура сільського населення Волинської області за економічною активністю

\begin{tabular}{|l|c|c|c|c|c|c|c|}
\hline \multirow{2}{*}{ Категорії населення } & \multicolumn{2}{|c|}{2016 p. } & \multicolumn{2}{c|}{ у 2017 p. } & \multicolumn{3}{c|}{2018 p. } \\
\cline { 2 - 9 } & $\begin{array}{c}\text { населен- всьог, } \\
\text { тис. осіб }\end{array}$ & $\begin{array}{c}\text { в т.ч. } \\
\text { сільсь- } \\
\text { ке, тис. } \\
\text { осіб }\end{array}$ & $\begin{array}{c}\text { населен- } \\
\text { ня, всього, } \\
\text { тис. осіб }\end{array}$ & $\begin{array}{c}\text { в т.ч. } \\
\text { сільсь- } \\
\text { ке, тис. } \\
\text { осіб }\end{array}$ & $\begin{array}{c}\text { населен- } \\
\text { ня, всього, } \\
\text { тис. осіб }\end{array}$ & $\begin{array}{c}\text { в т.ч. } \\
\text { сільс., } \\
\text { тис. } \\
\text { осіб }\end{array}$ & $\begin{array}{c}\text { в \% до } \\
\text { всьо- } \\
\text { го }\end{array}$ \\
\hline $\begin{array}{l}\text { Економічно активне } \\
\text { населення }\end{array}$ & 431,8 & 196,1 & 418,1 & 184,1 & 419,0 & 185,5 & 44,3 \\
\hline - працездатного віку & 426,3 & 194,0 & 413,5 & 183,4 & 414,4 & 183,8 & 44,4 \\
\hline Зайняті & 382,1 & 168,0 & 366,0 & 157,8 & 371,1 & 161,5 & 43,5 \\
\hline - працездатного віку & 376,6 & 165,9 & 361,4 & 156,4 & 366,5 & 159,8 & 43,6 \\
\hline Безробітні & 49,7 & 28,1 & 52,1 & 27,0 & 47,9 & 24,0 & 50,0 \\
\hline $\begin{array}{l}\text { Економічно } \\
\text { неактивне населення }\end{array}$ & 317,2 & 147,8 & 331,6 & 160,6 & 330,1 & 161,1 & 48,8 \\
\hline
\end{tabular}




\begin{tabular}{|l|l|l|l|l|l|l|l|}
\hline - працездатного віку & 223,7 & 106,8 & 231,0 & 116,5 & 224,8 & 115,5 & 51,4 \\
\hline
\end{tabular}

Джерело: розраховано за даними [8, с. 59].

Проведене дослідження свідчить про те, що для сільського населення характерним є вищий рівень зайнятості серед осіб віком $35-39$ років $(86,6 \%$ ), на другому місці - вікова ланка 40-49 років $(81,2 \%)$. Найважче знайти роботу сільським жителям у віці 15-24 років, де рівень безробіття складає 23,8 \%, що на 4,4 \% вище середнього показника по області у даній віковій категорії На сучасному етапі рівень зайнятості сільської молоді у віці 25-34 роки скорочується, а рівень зайнятості населення старше 50 років, та навіть старше працездатного віку, зростає, при чому надто швидкими темпами, що свідчить про загальне старіння сільського населення. У Волинській області дуже низький офіційний попит на робочу силу, працівників аграрного сектору. Станом на 1.012019 р. навантаження на одну вакансію склало лише 11 безробітних. На цей період кількість зареєстрованих безробітних в сільській місцевості склала лише 962 особи працездатного віку, що становить 12,3 \% від всіх незайнятих в області.

Добре розвинута соціальна інфраструктура дає можливість послідовно скорочувати невиправдану міграцію і плинність кадрів та на цій основі забезпечувати формування стабільних трудових колективів в існуючих аграрних формуваннях. Окремі показники, які характеризують стан розвитку соціальної інфраструктури сільської місцевості Волинської області наведено в табл. 3.

Таблиця 3

Стан розвитку соціальної інфраструктури в сільській місцевості Волинської області

\begin{tabular}{|c|c|c|c|c|c|c|}
\hline \multirow[b]{2}{*}{ Показники } & \multicolumn{5}{|c|}{ Роки } & \multirow{2}{*}{$\begin{array}{c}2018 \mathrm{p} . \\
\text { До } \\
2010 \mathrm{p} . \\
(+,-)\end{array}$} \\
\hline & 2010 & 2015 & 2016 & 2017 & 2018 & \\
\hline $\begin{array}{l}\text { Сільський житловий фонд, тис. } \\
\text { м² заг. площі }\end{array}$ & 12045 & 12759 & 12937 & 13123 & 13299 & 1254 \\
\hline $\begin{array}{l}\text { У середньому на } 1 \text { сільського } \\
\text { жителя, } \text { м }^{2}\end{array}$ & 22,6 & 25,5 & 25,9 & 26,3 & 26,7 & 4,1 \\
\hline $\begin{array}{l}\text { Кількість дитячих дошкільних } \\
\text { закладів, од. }\end{array}$ & 336 & 373 & 373 & 375 & 373 & 37 \\
\hline $\begin{array}{l}\text { Кількість місць в дитячих } \\
\text { закладах, тис. од. }\end{array}$ & 9,2 & 10,7 & 10,9 & 11,4 & 11,6 & 2,4 \\
\hline Охоплення дітей закладами, \% & 28 & 34 & 35 & 36 & 38 & 10 \\
\hline Кількість клубних закладів, од & 623 & 627 & 628 & 628 & 633 & 10 \\
\hline Кількість бібліотек, од. & 491 & 486 & 486 & 484 & 478 & -13 \\
\hline
\end{tabular}

Джерело: розраховано за даними [8, с. 128, 139, 310].

На кінець 2018 р. в області нараховувалось 485 закладів дошкільної освіти, 3 яких понад три чверті - знаходились в сільській місцевості. В них виховувалось 37,9 тис. дітей, що на $1,8 \%$ менше, ніж на кінець 2017 р. Завантаженість закладів дошкільної освіти становила 128 дітей в розрахунку на 100 місць (в Україні - 108), причому в міських поселеннях - 141, в сільській місцевості - 108. Охоплення дітей закладами дошкільної освіти за рік зросло з 55 \% до 57 \%.

Нині найбільшою проблемою на Волині є високий рівень безробіття, міграція, самозайнятість значної частини сільського населення - i, як наслідок, - низький рівень доходів та життя людей. Розвиток сільських територій прямо залежить від якості управління трудовим потенціалом (забезпечення умов для його збереження i відтворення, створення можливостей для ефективного прикладання трудової діяльності, регулювання мобільності працівників тощо). 
Незважаючи на позитивні зрушення в сільському господарстві області існує ще багато невирішених проблем. Зокрема, на регіональному рівні все ще зберігається тенденція щодо недооцінювання ролі сільських територій у загальній структурі економіки областей України. Основним видом виробництва серед сільських територій України залишається аграрне виробництво. При цьому нерозвиненими $\epsilon$ несільськогосподарські види діяльності. Це посилює кризові тенденції в розвитку сільських територій, активізує процеси міграції працездатного сільського населення до міст. Нині ключовою реформою є децентралізація. Її основні цілі - переорієнтувати в зворотний бік сільську міграцію, боротьба 3 бідністю, розширення зайнятості населення, забезпечення рівних можливостей i задоволення потреб населення, покращення якості життя, можливості для розвитку особистості та поліпшення стану соціального розвитку. Між міськими і сільськими територіями повинно бути досягнуто більш справедливого балансу бюджетних витрат, капіталовкладень в інфраструктуру, збільшення фінансування програм економічного розвитку сільських територій.

Перспективний план формування територій Волинської області затверджено розпорядженням Кабінету Міністрів України від 23 вересня 2015 р. № 993 (в редакції розпорядження Кабінету Міністрів України від 21 червня 2017 р. № 422-р. та змінами, внесеними згідно з Розпорядженням КМУ № 328-р від 16.05.2018р.) [9]. Нині на території області - 51 ОТГ: 1 район вкритий ОТГ на $100 \%$, 9 районів - 50-99 \%, 6 районів - 1-49\%. Волинська область в загальноукраїнському рейтингу областей щодо формування ОТГ займає 4 сходинку.

Так, у 2015 році було утворено 5 ОТГ, у 2016 р. - 10, у 2017 р. - 25, а у $2018-11$ ОТГ. Загалом перспективним планом передбачено створення 75 ОТГ на Волині. Всього в області 412 територіальних громад. Площа об'єднаних територіальних громад - 10770,2 км², що становить 53,47 \% від загальної площі території Волинської області. Із загальної чисельності населення в області (1037,9 тис. осіб) 359,1 тис. осіб (34,6 \%) проживають в ОТГ. Варто зазначити, що в кінці 2018 р. - 22 грудня чотирнадцять об'єднаних територіальних громад отримали 24234,69 гектарів земель сільськогосподарського призначення поза межами населених пунктів. Це четверта передача землі Волинським ОТГ. Третя відбулася 27 вересня 2018 року, тоді вісім Волинських об'єднаних територіальних громад отримали 15595,09 гектарів земель поза межами населених пунктів с.-г. призначення. Друга відбулася 6 червня 2018 року - сім Волинських ОТГ отримали землю сільськогосподарського призначення поза межами населених пунктів. У червні 2018 р. волинським ОТГ передали близько 9 тисяч гектарів. Перша передача відбулася 27 лютого 2018 р. - Городищенська ОТГ отримала 962 гектари. Надалі земельні ділянки передаватимуть ОТГ у 2019 році.

На території області функціонує 26 ЦНАПів. Також у перших двох раундах Програми «U-LEAD з Європою» в частині створення та модернізації ЦНАПів 15 Волинських ОТГ стали переможцями. До того ж на території області підписано 9 договорів про співробітництво ОТГ, якими скористалося 27 громад. Щодо медицини та освіти, то на Волині є 3 госпітальні округи (1 госпітальна рада) і 30 опорних шкіл (19 з них в ОТГ). Станом на 1.01.2019 р. 40 громад вже прийняли у комунальну власність 234 заклади загальної середньої освіти області. Загалом в опорних закладах області навчається 14405 учнів, з них у опорних закладах об'єднаних територіальних громад 9339 учнів. Крім того, Волинські ОТГ, як додатковий ресурс росту отримали землю поза межами населених пунктів сільськогосподарського призначення.

Таблиця 4

Основні показники результатів децентралізаційних перетворень на Волині

\begin{tabular}{|l|l|l|c|c|c|}
\hline \multirow{2}{*}{$№$} & Райони & \multicolumn{4}{|c|}{ Показники станом на 1.01.2019 р. } \\
\cline { 3 - 5 } & & $\begin{array}{l}\text { Кількість рад, } \\
\text { що об'єднались }\end{array}$ & $\begin{array}{c}\text { Кількість } \\
\text { ОТГ }\end{array}$ & $\begin{array}{c}\text { Площа ОТГ, } \\
\text { км }^{2}\end{array}$ & $\begin{array}{l}\text { Кількість } \\
\text { населення, }\end{array}$ \\
\hline
\end{tabular}




\begin{tabular}{|l|l|c|c|c|c|}
\hline & & & & осіб \\
\hline 1. & Володимир-Волинський & 21 & 4 & 932,55 & 23297 \\
\hline 2. & Горохівський & 4 & 1 & 170,92 & 9032 \\
\hline 3. & Іваничівський & 21 & 4 & 447,13 & 22768 \\
\hline
\end{tabular}

\begin{tabular}{|c|l|c|c|c|c|}
\hline \multicolumn{1}{|c|}{2} & \multicolumn{3}{c|}{ Продовж.табл. 4.} \\
\hline 1 & \multicolumn{2}{|c|}{2} & 4 & 5 & 6 \\
\hline 4. & Камінь-Каширський & 5 & 1 & 301,27 & 5186 \\
\hline 5. & Ківерцівський & 14 & 4 & 684,13 & 36921 \\
\hline 6. & Ковельський & 23 & 6 & 1356,72 & 31779 \\
\hline 7. & Локачинський & 12 & 3 & 479,08 & 11386 \\
\hline 8. & Луцький & 28 & 9 & 825,31 & 60318 \\
\hline 9. & Любешівський & 16 & 1 & 1108,95 & 28890 \\
\hline 10. & Любомльський & 21 & 4 & 1267,19 & 34587 \\
\hline 11. & Маневицький & 12 & 2 & 747,42 & 18892 \\
\hline 12. & Ратнівський & 6 & 4 & 911,97 & 27552 \\
\hline 13. & Рожищенський & 16 & 1 & 180,00 & 5355 \\
\hline 14. & Старовижівський & 7 & 4 & 782,62 & 22354 \\
\hline 15. & Турійський & 3 & 1 & 267,52 & 12132 \\
\hline 16. & Шацький & 222 & 51 & 307,45 & 8694 \\
\hline & Всього по області & & 10770,23 & 359143 \\
\hline
\end{tabular}

Джерело: складено за даними: https://decentralization.gov.ua/areas/0332/rayons?page=2

Варто зазначити, що на Волині рівень освоєнності інфраструктурної субвенції у 2018 р. сягнув понад 99 \%, що є досить високим показником у порівнянні з іншими областями України. В області 15 ОТГ на 100 \% освоїли інфраструктурну субвенцію. 14 об'єднаних територіальних громад освоїли субвенцію на 99,9 \% і повернули до бюджету незначні кошти, наприклад, Голобська - 7 гривень, Заборольська - 9 гривень i Колківська -3 гривні.

За даними Волинського Центру розвитку місцевого самоврядування, який створений за підтримки Програми «U-LEAD з Європою» та Міністерства регіонального розвитку, будівництва та житлово-комунального господарства України, власні надходження у загальний фонд місцевих бюджетів за 2018 рік склали 814189,1 тис. грн. Це складає 111,39 \% річного плану. Із 40 громад, що повноцінно функціонують та мають прямі бюджетні стосунки з Державним бюджетом, 39 виконали плани доходів. Варто зазначити, що при складанні бюджетів на 2018 р. громадами було заплановано 610474,5 тис. грн. власних доходів загального фонду. Тобто, якщо не враховувати внесених у бюджети протягом року змін, першопочатковий плановий показник власних надходжень перевищено громадами на 203714,6 тис. грн. У 2018 р. було заплановано 610,474 млн грн власних доходів, а отримано 814,189 млн грн доходів (на 203,715 млн грн або $33,37 \%$ ) більше.

Проаналізувавши сучасний стан, здобутки та проблеми децентралізаційних перетворень на сільських територіях Волинської області можна узагальнити, що реформа має як позитивні так і негативні наслідки. Позитивним $є$ те, що здійснюється секторальна реформа, тобто у децентралізації задіяні різні сфери життя селян - шкільна та дошкільна освіта, медицина, житлово-комунальне господарство та ін.; посилюються можливості ОТГ для надання високоякісних послуг громадянам, зокрема створюються ЦНАПи; покращується матеріально-технічна база шкіл та дитсадків, ремонтуються приміщення, здійснюється розвиток «Нової української школи» (НУШ), створюються центри первинної медичної допомоги та ін.; виникає так зване «муніципальне співробітництво між ОТГ» - нині 23 ОТГ Волині уклали 12 договорів про співробітництво у сферах: ЖКГ - 1; благоустрій - 1; освіта, охорона здоров'я, соціальне забезпечення - 2; інші - 8; відбувається значний комунікаційний розвиток, йде просування ОТГ в інформаційному просторі: кожна із громад старається знайти свою родзинку; проводяться фестивалі, ярмарки, виставки; створюються історичні музеї та експозиції; розробляються власні логотипи тощо. 
Для покращання соціально-економічного розвитку сільської місцевості Волинської області в умовах децентралізації доцільним вбачається проведення SWOTаналізу. Результати SWOT-аналізу дозволяють створити початкову інформаційну базу для іiі наступної обробки, дають змогу адекватно оцінити рівень децентралізаційних перетворень на селі, виявити переваги та визначити напрямки дальшого прикладання зусиль щодо забезпечення сталого соціально-економічного розвитку сільських територій та зростання добробуту й якості життя сільських жителів (табл. 5).

Таблиця 5

SWOT-аналіз процесу децентралізації для соціально-економічного розвитку сільських в окремих (Шацькій, Дубечнівській тарй.бррій Волинснької облдесті до необхідних фінансово-кредитних, - тісна співпраця створених ОТГ із Волинським інформаційних та земельних ресурсів;

ЦРМС у напрямку надання інформаційно- • недостатнє виділення коштів підприємствами консультаційних послуг, проведення навчань та корпоративного сектора на утримання соціальної спеціалізованих тренінгів; сфери села;

- оскільки в області створено 27 ЦНАПів, то за допомогою участі у Програмі «U-LEAD 3 Європою» продовження їх створення та модернізація;

• низька нормативно-грошова оцінка зумовлює низьку орендну плату за землю, яка формує доходну частину бюджетів ОТГ;

- зростання комунікаційних можливостей та просування ОТГ у інформаційному просторі.

• посилення впливу факторів невизначеності та ризику на виробничо-господарську діяльність суб'єктів агробізнесу на території ОТГ. 
Проведений аналіз факторів внутрішнього й зовнішнього середовища процесу децентралізації та ранжування їх за рівнем впливу соціально-економічний розвиток сільських територій Волинської області дозволив сформувати конкретний перелік його слабких і сильних сторін, а також загроз і можливостей. Саме комплексний аналіз сильних та слабких сторін процесу децентралізації в області дає можливість оцінити іiі реальний стан, виокремити здобутки та обгрунтувати перспективи. В області пропонується створити 4 адміністративних райони (повіти). Подальші перспективи реформування адміністративно-територіального устрою й територіальної організації публічної влади у Волинській області вбачаємо у формуванні об'єднаних територіальних громад, спроможних забезпечувати якісне надання основних публічних послуг з їх близькістю до сільських мешканців.

Висновки. Отже, наразі відбуваються зміни у правовому полі функціонування територіальних громад Волині, які покликані стимулювати їх до об'єднання i посилення спроможності, через різні соціально-правові й фінансово-економічні механізми самостійно вирішувати питання місцевого значення. Законодавчо ініційовано перехід бюджетів об'єднаних територіальних громад до прямих міжбюджетних відносин з Державним бюджетом, а також значно розширено джерела формування їхніх доходів [10]. При цьому, основною формою фінансового забезпечення територіальних громад залишається бюджетне фінансування, від якості якого залежить рівень їх економічного та соціального розвитку. Тому доцільним вбачається наділення територіальних громад більшими ресурсами, мобілізація внутрішніх резервів та їх ефективне використання, залучення інвестиційних коштів.

Варто зазначити, що децентралізація як процес перерозподілу повноважень i функцій потенційно містить ризики посилення відцентрових тенденцій у суспільнополітичній сфері, як і ризики макроекономічної нестабільності через ймовірне посилення асиметричності регіонального розвитку. Вважаємо, що недоцільно очікувати швидких результатів від процесу децентралізації управління та здійснюваного в його межах об'єднання сільських територіальних громад, оскільки позитивний вплив на соціально-економічний розвиток певної території можна одержати лише у середньо- чи довгостроковій перспективі. Адже на шляху до сталого соціально орієнтованого розвитку сільських поселень Волинської області зберігаються значні соціальнодемографічні та соціально-економічні обмеження і ризики, обумовлені тенденціями попереднього періоду їхнього розвитку і децентралізаційними змінами у всій системі управління.

\section{Список бібліографічного опису:}

1. Імплементація європейських засад сільського розвитку в Україні : монографія / за ред. чл.-кор. НАН України О.М. Бородіної ; НАН України, ДУ «Ін-т екон. та прогнозув. НАН України». К., 2018. 300 с.

2. Борщевський В.В., Куліш І.М., Залуцький І.Р., Цимбаліста Н.А. Збалансований розвиток сільських територій Волинської області: оцінка, проблеми, перспективи: допов. записка. Львів : ДУ «Інститут регіональних досліджень імені М.І. Долішнього НАН України», 2015. 65 с.

3. Інклюзивний розвиток сільської економіки в умовах глобалізаційних викликів / [Т.О. Зінчук, Т.В. Усюк. В.С. Данкевич та ін.]; за ред. д.е.н., проф. Т.О. Зінчук, к.е.н., Н.М. Куцмус. К: «Центр учбової літератури»», 2017. 352 с.

4. Малік М.Й., Хвесик М.А. Сталий розвиток сільських територій на засадах раціонального природокористування та еколого-безпечного агропромислового виробництва. Економіка АПК. 2010. № 5. С. 3-12.

5. Прокопа I. В. Життєзабезпечення сільського населення : наслідки старих та орієнтири нових реформ. Економіка $i$ прогнозування. 2015. № 1. С. 121-130.

6. Тимошенко М. М. Стратегія сталого розвитку сільських територій України та економічний механізм ії реалізації: монографія. Житомир: Видавець ОО Євенок, 2018. 332 с.

7. Tymoschenko M., Sokolova A., Sychuk L. Innovative basis for ensuring of integration the agricultural education, science and production: problems and prospects / Organizational-economic mechanism of management innovative development of economic entities : collective monograph / edited by M. Bezpartochyi, in 3 Vol. / higher School of Social and Economic. Przeworsk: WSSG, Vol.3. 2019. p. 374-385.

8. Статистичний щорічник Волинь - 2018 / за ред. В. Ю. Науменка. Луцьк, Голов. управ. статистики у Волинській області. Луцьк, 2019. 448 с.

9. Перспективний план формування територій громад Волинської області, затверджений розпорядженням Кабінету Міністрів України від 23 вересня 2015 р. № 993 (в редакції розпорядження Кабінету Міністрів України від 21 червня 2017 p. № 422-p). URL :file:///C:/WINDOWS/Temp/Rar\$EXa0.180/d447956.htm. (дата звернення 4.01.2020). 
10. Про схвалення Концепції реформування місцевого самоврядування та територіальної організації влади в Україні: Розпорядження Кабінету Міністрів України від 01.04.2014 p. № 333 p. URL: http://www.minregion.gov.ua/attachments/ contentattachments/3557/Rozyasnennya_zmin.pdf. (дата звернення 22.01.2020).

\section{Reference:}

1. Borodina, O. M. (Eds.). (2018). Implementatsiia yevropeiskykh zasad silskoho rozvytku v Ukraini : monohrafiia [Implementation of European rural development principles in Ukraine: monograph]. Kyiv : DU «In-t ekon. ta prohnozuv. NAN Ukrainy». [in Ukrainian]. 2. Borshchevskyi, V. V., Kulish, I. M., Zalutskyi, I. R., Tsymbalista, N. A. (2015). Zbalansovanyi rozvytok silskykh terytorii Volynskoi oblasti: otsinka, problemy, perspektyvy: dopov. zapyska [Balanced development of rural territories of Volyn region: assessment, problems, prospects: suppl. note]. Lviv : DU «Instytut rehionalnykh doslidzhen imeni M. I. Dolishnoho NAN Ukrainy». [in Ukrainian].

3. Zinchuk, T. O. \& Kutsmus, N. M. (Eds.). (2017). Inkliuzyvnyi rozvytok silskoi ekonomiky v umovakh hlobalizatsiinykh vyklykiv [Inclusive development of the rural economy in the face of globalization challenges]. Kyiv : «Tsentr uchbovoi literatury». [in Ukrainian].

4. Malik, M. I., \& Khvesyk, M. A. (2010). Stalyi rozvytok silskykh terytorii na zasadakh ratsionalnoho pryrodokorystuvannia ta ekolohobezpechnoho ahropromyslovoho vyrobnytstva [Sustainable development of rural territories on the basis of rational environmental management and environmentally safe agro-industrial production]. Ekonomika APK. [APK economy], 5, 3-12. [in Ukrainian].

5. Prokopa, I. V. (2015). Zhyttiezabezpechennia silskoho naselennia : naslidky starykh ta oriientyry novykh reform [Rural livelihoods: implications of old and benchmarks for new reforms]. Ekonomika i prohnozuvannia. [Economics and forecasting], 1,121-130. [in Ukrainian]. 6. Tymoshenko, M. M. (2018). Stratehiia staloho rozvytku silskykh terytorii Ukrainy ta ekonomichnyi mekhanizm yii realizatsii: monohrafiia [Strategy of sustainable development of rural territories of Ukraine and economic mechanism of its implementation: monograph]. Zhytomyr : OO Jevenok. [in Ukrainian].

7. Tymoschenko, M., Sokolova, A., Sychuk, L. (2019). Innovative basis for ensuring of integration the agricultural education, science and production: problems and prospects. Organizational-economic mechanism of management innovative development of economic entities : collective monograph / edited by M. Bezpartochyi, in 3 Vol. higher School of Social and Economic. Przeworsk: WSSG, Vol.3. [in Poland]. 8. Naumenko, V. Yu. (Eds.). (2019). Statystychnyi shchorichnyk Volyn - 2018. Lutsk,: Holov. uprav. statystyky u Volynskii oblasti. [in Ukrainian].

9. Perspektyvnyi plan formuvannia terytorii hromad Volynskoi oblasti, zatverdzhenyi rozporiadzhenniam Kabinetu Ministriv Ukrainy vid 23 veresnia 2015 r. № 993 (v redaktsii rozporiadzhennia Kabinetu Ministriv Ukrainy vid 21 chervnia 2017 r. № 422-r). Retrieved from file:///C:/WINDOWS/Temp/Rar\$EXa0.180/d447956.htm. [in Ukrainian].

10. Rozporiadzhennia Kabinetu Ministriv Ukrainy (2014). Pro skhvalennia Kontseptsii reformuvannia mistsevoho samovriaduvannia ta terytorialnoi orhanizatsii vlady v Ukraini : pryiniate 01.04.2014 r. № 333 r. minregion.gov.ua. Retrieved from http://www.minregion.gov.ua/ attachments/contentattachments/3557/Rozyasnennya_zmin.pdf. [in Ukrainian].

Дата подання публікації 04.03.2020 р. 